\title{
Bedload Sediment Concentration of Sungai Kahang Downstream Kahang Dam in Johor
}

\author{
Mohd Shalahuddin Adnan ${ }^{1, *}$, Muhammad Nda ${ }^{1,2}$, Mohd Shazrin Zakaria ${ }^{1}$, \\ Mohamad Arif Suhadak ${ }^{1}$, Mohd Adib Mohammad Razi ${ }^{1}$, Mohd Azlan Mohd \\ Yusoff ${ }^{1}$, Siti Nazahiyah Rahmat ${ }^{1}$, Muhammad Salleh Abustan ${ }^{1}$, Saiful Azhar \\ Ahmad Tajudin ${ }^{3}$ \\ ${ }^{1}$ Department of Water and Environmental Engineering, Universiti Tun Hussein Onn Malaysia,86400 Batu Pahat, Parit \\ Raja Johor, Malaysia. \\ ${ }^{2}$ Department of Civil Engineering, School of Engineering Technology, The Federal Polytechnic Bida, P.M.B 55 Niger \\ State - NIGERIA. \\ ${ }^{3}$ Department of Infrastructure and Geomatic Engineering, Universiti Tun Hussein Onn Malaysia,86400 Batu Pahat, \\ Parit Raja Johor, Malaysia.
}

Received 01 January 2018; accepted 15 April 2018, available online 07 May 2018

\begin{abstract}
Dams construction globally on rivers have generated a significant adjustment to stream hydrology and sediment dynamics. The impoundment of rivers by dam reservoirs will trap the sediments following freely downstream the river channel. Kahang dam is constructed to impound Sungai Kahang (Kahang River) for water supply purposes; this may have adverse effects downstream the dam by starving the river its natural sediments and changing the river flow. This study evaluates the bedload sediments and river discharge downstream the dam by taking field measurements, using the area-velocity and single increment method at three selected gauging locations $\left(\mathrm{St}_{0}, \mathrm{St}_{1}, \mathrm{St}_{2}\right)$. The results obtained between January and July 2017 show the highest bedload discharge for all the gauging Stations to be 0.0736 tones/day at $\mathrm{St}_{0}$ and 0.0077 tones/day at $\mathrm{St}_{2}$ while the river flow remains relatively steady between $0.528 \mathrm{~m}^{3} / \mathrm{s}$ to $2.534 \mathrm{~m}^{3} / \mathrm{s}$. The high bedload discharge recorded can be attributed to the anthropogenic activities going on during external construction works going on, as lower bedload concentration values followed immediately after the external construction work was completed.
\end{abstract}

Keywords: Bedload, suspended solid, Kahang River,

\section{Introduction}

Dams are constructed on the river course to harness water for so many purposes, i.e., water supply, power generation, and irrigation. The barriers help to preserve and store water for future purposes so that during the period of need the water in the reservoir is utilized, in so doing the natural flow of the river is regulated[1]. Rivers transport sediment, as well as water to reservoirs and dam intensely, hampers the outflow of water and sediment downstream thereby creating river reach characterized by meager flow rates and sediment[2]. Sediment is a product of erosion or wearing away of the land surface by the action of rains, ice and gravity and human activities, the process of this gradual movement of the topsoil by heavy rain droplet and other vices are referred to as sediment transport[3].

Sediment transport occurs when there is an interface between a moving fluid and an erodible boundary. The activity at this interface is multifaceted (since two materials are involved) and the flow is no longer a simple fluid flow once sediment is being transported. Sediment transport can be considered as occurring in two forms, bedload sediments and suspended sediments depending on the size of the particles and the flow conditions. The bedload is the lager material particles that are transported along or near the river channel bed. While the suspended sediments (may contain some wash load) involves movements of smaller particles in the water column within the river channel, not governed by bed material properties and composition but, by upstream supply rate. As water movement increases, the particles may go in suspension and remain thus due to the turbulent fluctuations and get carried downstream by stream flow [4-6].

Nilsson et al. [7] confirm that dam constructions and water diversion structures for energy and water needs have consistently altered river systems. Human activities have simultaneously increase river sediment through soil erosion and decreasing it through sediment accumulation in reservoirs[8]. Estimates of fluvial sediments deposited into the oceans amount to over 20 billion tones per year $(\mathrm{Bt} / \mathrm{y})$, it is projected that the worlds over 45,000 large 
reservoirs can adequately trap as much as $4-5 \mathrm{Bt} / \mathrm{y}$. Study of the river bed sediments (bedload) is a valuable tool to verify the changes to the natural river sediment pattern caused by reservoir impoundment[9]. For example, the Three Gorges Dam does not substantially modify the stream flow, but the loss of sediment from the channel system has a substantial impact on bed mobility[10].

Bedload sediment direct measurement in open channels is problematic, the introduction of suitable sampler into the fluid is not devoid of technical issues. Furthermore, the few number of measurements available indicates a periodicity of bedload discharge that complicates further the spatial pattern of sediment transport already established as characteristics of the stream bed. In conclusion, previous research shows that bedload contributes between 6 and 24 percent of total sediment yield for different rivers yet, the importance of bedload determining the pattern of channel sediment rates and bringing about changes in channel cross-sectional geometry exceeds its proportional contribution to total catchment sediment yield. Bedload discharge comprehensive measurement is of immense value to the understanding of the general river hydraulics[11]-[13].

\section{Methodologies}

\subsection{Study Area}

Kluang is a district in the Malaysian state of Johor located on coordinate $2.0301^{\circ} \mathrm{N}, 103.3185^{\circ} \mathrm{E}$ (Figure 1). The location of the study area is Kahang Dam which is situated near Felda Kahang Timur with a raw water storage capacity of 21 million cubic meters and the total area of about 860 hectares. Kahang Dam is built to impound Sungai Kahang (Kahang River) and other smaller tributaries. There are three gauging stations where the sampling is carried out, and they are identified based on their distance from the dam stilling basin. $\mathrm{St}_{\mathrm{o}}$ is $100 \mathrm{~m}$ away from the stilling basin while $\mathrm{St}_{1}$ and $\mathrm{St}_{2}$ are $175 \mathrm{~m}$ and $500 \mathrm{~m}$ respectively.

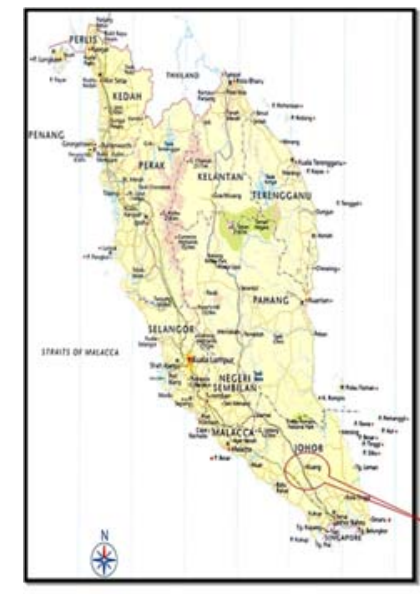

Fig. 1 Location of study area

\subsection{Sampling Technique}

An essential part of completing this study is the collection of data. Three sampling locations were selected downstream of Kahang dam namely; station zero $\left(\mathrm{St}_{0}\right)$, station one $\left(\mathrm{St}_{1}\right)$ and station two $\left(\mathrm{St}_{2}\right)$. These sites were chosen based on the preliminary survey carried out in the study area to identify cross sections where the river flow is relatively uniform and free from obstructions. The following data was collected from the three gauging stations between January to July 20017; flow rate, crosssectional area and bedload sediments.

\subsection{Discharge measurements}

River discharge measurement is defined as the measurement of water volume flowing through a crosssection per unit time, expressed in cubic meter per second $(\mathrm{m} 3 / \mathrm{s})$, using the river flow rate and cross-sectional area of the river. The discharge measurements of the gauging stations were determined using the AEM 1-D electric, magnetic current and speed meter, a pair of the peg, measuring tape and a graduated line using the velocity-area method.

\subsubsection{Velocity - Area method}

The cross-section of the stream at the gauging site was divided into elemental strips of equal width $b$, mean depth (d) at the center of each strip was measured using a measuring tape. The current meter is now lowered to a depth of $0.6 \mathrm{~d}$ below the water surface in shallow depths (one-point method) and to a depth of $0.2 \mathrm{~d}$ and $0.8 \mathrm{~d}$ (twopoints method) in deep waters, at the center of each strip. The discharge is given by equation 1

$$
Q=V A
$$

where;

$$
\begin{aligned}
& \mathrm{Q}=\text { discharge } \\
& \mathrm{A}=\text { cross- sectional area } \\
& \mathrm{V}=\text { velocity }
\end{aligned}
$$

The total discharge for a current meter measurement is the summation of the products of the partial areas of the stream cross section and their respective average velocity as given in equation (2).

$$
Q=\sum_{i=1}^{n} a_{i} v_{i}
$$

where;

$\mathrm{Q}=$ total discharge $\left(\mathrm{m}^{3} / \mathrm{s}\right)$,

$\mathrm{a}_{\mathrm{i}}=$ cross sectional area $\left(\mathrm{m}^{2}\right)$, for the $\mathrm{i}^{\text {th }}$ segment of the $\mathrm{n}$ segments into which the cross- section is divided. $\mathrm{v}_{\mathrm{i}}=$ mean velocity $(\mathrm{m} / \mathrm{s})$ of the flow normal to the $\mathrm{i}^{\text {th }}$ segment.

\subsection{Bedload sediment measurement}

Bedload sediment transport rate and the flow rate of water close to the bed vary substantially concerning both space and time. Hence, any sample obtained at a given point may not be representative of the mean transport rate for a reasonable interval of time because the bed particles 
move intermittently at a mean velocity much less than that of the water. The use of Helley-smith sampler was employed in this study.

\subsubsection{Helley - Smith bedload sampler}

The sampler consists of an expanding nozzle, sample bag, and frame enables collection of bedload particle moving close to the river channel bed. The sampler has a 3inch by 3 -inch square entrance nozzle an area ratio (ratio of nozzle exit to entrance area) of 3.22. The total weight of the sampler design is 66 pounds, requiring the use of a cable-reel suspension system. Bedload samples are collected from the selected sampling sites $\left(\mathrm{St}_{0}, \mathrm{St}_{1}\right.$ and $\left.\mathrm{St}_{2}\right)$, starting at one river bank and proceeding to the other. The river cross section was subdivided into four equal verticals, one sample collected at each vertical at a time along the cross-section and then return to the starting point. Samples were collected at the midpoint of the evenly spaced divisions at an equal time interval of ten minutes each. Trapped samples in the Helley- Smith sampler is emptied into the weighing dish and weighed $(\mathrm{g})$. The total bedload discharge for the cross-section is computed by equation (3).

$$
Q_{B}=K \frac{W_{T}}{t_{T}} M_{T}
$$

where;

$\mathrm{Q}_{\mathrm{B}}=$ bedload discharge (tones/day)

$\mathrm{W}_{\mathrm{T}}=$ total width of stream from were samples are collected.

$\mathrm{t}_{\mathrm{T}}=$ total time the sampler was on the bed (secs)

$\mathrm{M}_{\mathrm{T}}=$ total mass of sample collected $(\mathrm{g})$

$\mathrm{K}=$ conversion factor \{grams to tons/day (for a 3 - inch nozzle $\mathrm{k}=0.381)\}$

\section{Results and Discussion \\ 3.1 River discharge}

Kahang dam is built on kahang river, and its tributaries to systematically regulate the natural river flow by storing and preserving the water to be used for water supply purposes in Kluang town and environs. Observations onsite show that the river flow has been quite slow, this was also confirmed by the stream gauging results of the three gauging stations (Table 1.).

Table 1. Flow measurements $\left(\mathrm{m}^{3} / \mathrm{s}\right)$ for the gauging stations

\begin{tabular}{cccc}
\hline St./Month & $\mathrm{St}_{0}$ & $\mathrm{St}_{1}$ & $\mathrm{St}_{2}$ \\
\hline Jan & - & 1.124 & 1.141 \\
Feb & 0.528 & 1.137 & 1.138 \\
March & 0.322 & 1.161 & 1.213 \\
April & 1.230 & 1.353 & 1.331 \\
May & 1.270 & 1.398 & 1.454 \\
June & 1.622 & 2.091 & 2.141 \\
July & 2.076 & 2.534 & 2.333 \\
\hline
\end{tabular}

From the results for the three gauging stations, the discharge values are not far from each other from one gauging station to the other with $0.322 \mathrm{~m}^{3} / \mathrm{s}$ measured at $\mathrm{St}_{0}$ in March 2017 which is the lowest for the period in view and $2.534 \mathrm{~m}^{3} / \mathrm{s}$ the peak value recorded in July 2017 at $\mathrm{St}_{2}$. Though the results show that there is a sharp upward change in the rate of the river discharge, these differences were observed at all the gauging stations as from June 2017.

Discharge measured in May and June at $\mathrm{St}_{0}$ are $1.270 \mathrm{~m}^{3} / \mathrm{s}$ and $1.622 \mathrm{~m}^{3} / \mathrm{s}$ respectively, but in the same gauging station in July $2017,2.076 \mathrm{~m}^{3} / \mathrm{s}$ was recorded this show there is an upward change in flow. Likewise, $\mathrm{St}_{1}$ have a considerably higher flow rate in July with $2.534 \mathrm{~m}^{3} / \mathrm{s}$ as compared to that of May and June with $1.398 \mathrm{~m}^{3} / \mathrm{s}$ and $2.091 \mathrm{~m}^{3} / \mathrm{s}$ respectively. Gauging station two $\left(\mathrm{St}_{2}\right)$ result pattern does not differ with the other locations as the flow rate for July 2017 is also a little higher than that recorded in prior months (May and June 2017) with $2.333 \mathrm{~m}^{3} / \mathrm{s}$. It was observed that an additional outlet of the dam is opened to release water downstream the river channel where the gauging sites are located, which is the reason for the increased flow regime in June and July 2017.

\subsection{Bedload sediment discharge}

The trend of bedload sediment discharge rate in the three gauging stations is shown in Figure 2. Bedload sediments in all locations have been unstable by series of noticeable upward and downward changes in concentration rates from January to July 2007. At $\mathrm{St}_{0}$ the lowest concentration 0.0305 tones/day was observed in July 2017 (Figure 2a) and at $\mathrm{St}_{1}$ it was about 0.0145 tones/day in July (Figure $2 \mathrm{~b}$ ) also, at $\mathrm{St}_{2}$ the lowest bedload discharge measured is 0.0077 tones/day in January (Figure 2c). Similarly, the highest bedload discharge measurements were recorded at $\mathrm{St}_{0} 0.0736$ tones/day, $\mathrm{St}_{1}$ 0.0553 tones/day and 0.0138 tones/day in April, March, and July respectively. There was a sharp rise in bedload discharge towards the end of the dam external construction work starting April 0.0736 tones/day at $\mathrm{St}_{0}$, and then gradual decline was experienced from May when construction works ended in June and July with 0.0439 tones/day and 0.0305 tones/day.

The reduction in the amount of bedload discharge was not only peculiar to $\mathrm{St}_{0}$ but across all other gauging locations with 0.0313 and 0.0339 tones/day in June at $\mathrm{St}_{1}$ and $\mathrm{St}_{2}$. Also, in June there was a further decline in bedload discharge 0.0148 and 0.018 tones/day for both gauging locations ( $\mathrm{St}_{1}$ and $\left.\mathrm{St}_{2}\right)$.

Figure 3 Shows a clustered representation of bedload discharge rate for all the gauging locations. It can be seen that $\mathrm{St}_{0}$ has the highest bedload discharge rate for the duration of measurements, this might be because station $\mathrm{St}_{0}$ is the nearest to the dam stilling basin about $100 \mathrm{~m}$ away.

While $\mathrm{St}_{2}$ bedload discharge is the lowest with little amounts discharged in January, February, March and July 2017 ( $0.0077,0.0103,0.0127$ tones/day), this station's location is also the farthest about $500 \mathrm{~m}$ downstream the dam. 


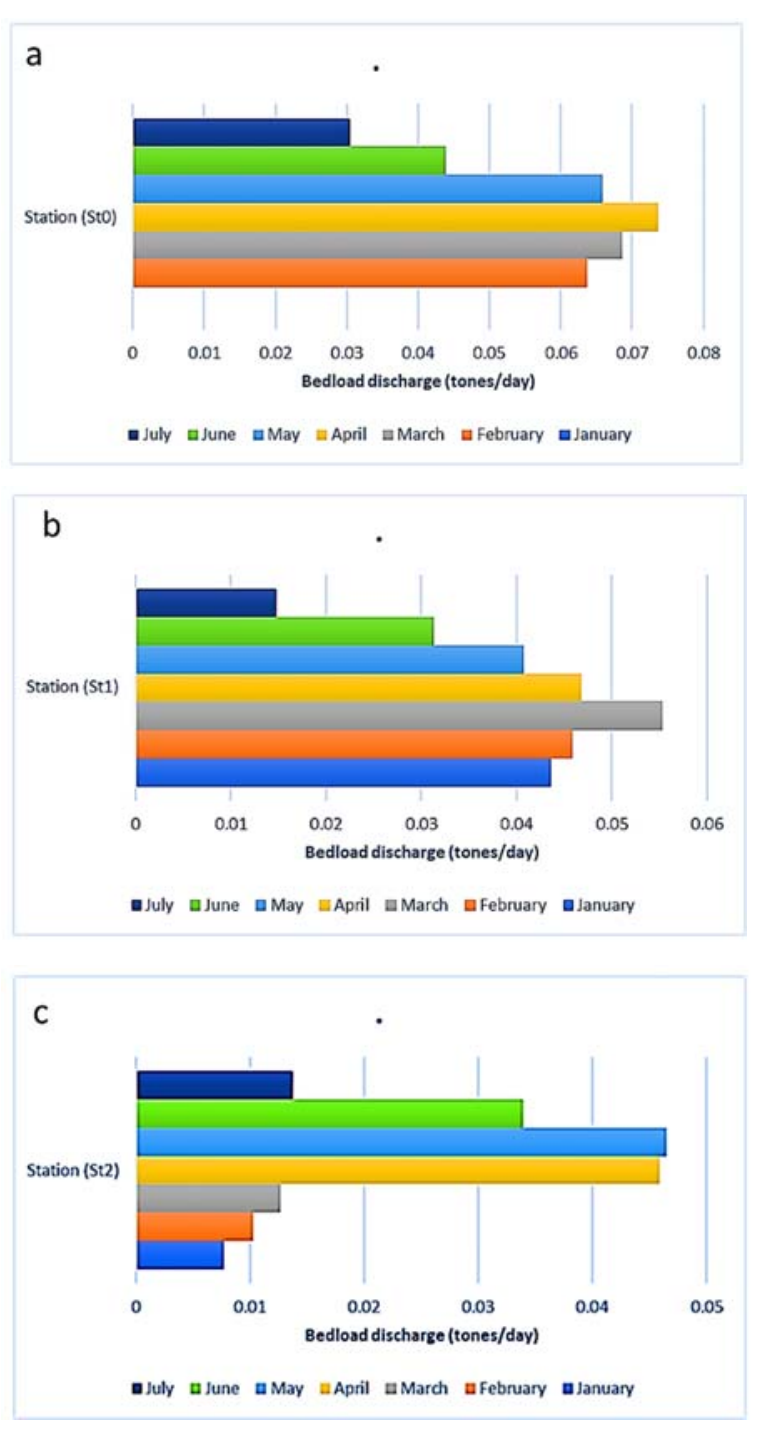

Fig. 2 Bedload discharge for a. $\mathrm{St}_{0}$, b. $\mathrm{St}_{1}$ and c. $\mathrm{St}_{2}$

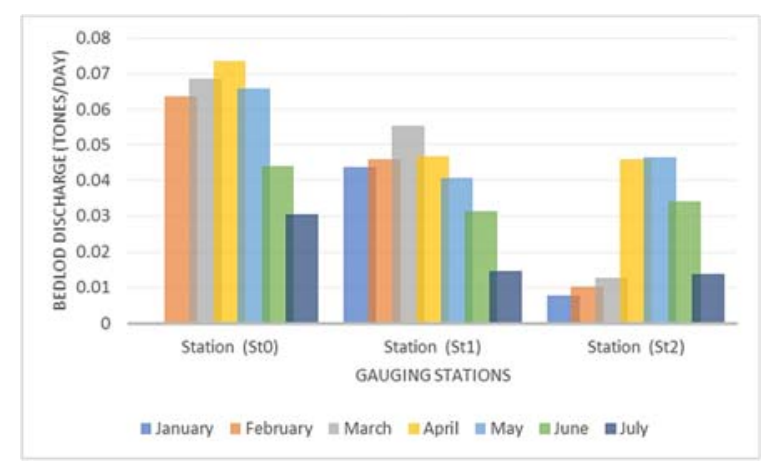

Fig. 3 Clustered Bedload discharge for $\mathrm{St}_{\mathrm{o}}, \mathrm{St}_{1}$, and $\mathrm{St}_{2}$

The results show that the higher amounts of sediment during the external construction work was primarily as a result of anthropogenic activities going on such as clearing and cutting of trees, movement of the workforce and heavy equipment, hauling and dumping of construction materials from one location to the other within the study area.It can also be observed from the results that immediately after the external works stopped in May, the sediment concentration starts reducing this shows that the higher concentration was not transported naturally by the river flow. But, the higher sediment measured was enhanced by the activities happening at that period.Similar studies by Kehui et al.[14] on Yangtze River reveals that the numerous amount of dams on the river have resulted in a severe change in sediment discharge while little impact is observed on water discharge. The authors also reported that the annual sediment discharge of Yangtze River after impoundment is estimated to have reduced by $60 \%$ because most of the sediments are trapped in the reservoir.The study on Yangtze River confirms that introduction of dam on natural rivers will tremendously decline the sediment meant to be naturally transported downstream the river channel.

\section{Conclusion}

Dams regulate river flows and have storage reservoirs in the headwater region. The result is that the downstream river channel flow is controlled which can affect almost the entire river. Such a change will modify the riparian zone of the river, the flood peak and hence frequency of overbank flooding. Evaporation losses and increased water use due to water impoundment often reduce downstream discharge. Furthermore, dams change the process of sediment cycling by trapping large sediment masses previously transported downstream. The results obtained between January and July 2017 show the highest bedload discharge for all the gauging Stations to be 0.0736 tones/day at St 0 and 0.0077 tones/day at $\mathrm{St} 2$ while the river flow remains relatively steady between $0.528 \mathrm{~m} 3 / \mathrm{s}$ to $2.534 \mathrm{~m} 3 / \mathrm{s}$. The higher sediment discharge was during the external works, immediately afterward there was decline which shows that the dam is already starving the downstream sediment discharge and reduced flow rate.

\section{Acknowledgement}

This paper was partly sponsored by Universiti Tun Hussein Onn Malaysia. The authors highly appreciate Universiti Tun Hussein Onn Malaysia (UTHM) for funding this research work under the Postgraduate Research Grant GPPS (U699).

\section{References}

[1] Wang,X., Li, X., Baiyinbaoligao, and Wu, Y. Maintaining the connected river-lake relationship in the middle Yangtze River reaches after completion of the Three Gorges Project, Int. J. Sediment Res.2017.

[2] You, X., Tang, J., Xu, J., and Chen, M. Impacts of the Reservoir on the Navigation Conditions of the Downstream Channel: Taking the Three Gorges Reservoir in the Middle Reaches of the Yangtze River as an Example, Int. J. Adv. Earth Sci. Eng., vol. 5, no. 1, 2016, pp. 447-448. 
[3] Dias, M.P., M. Lecoq, F. Moniz, and Rabaça, J.E.Can Human-made Saltpans Represent an Alternative Habitat for Shorebirds Implications for a Predictable Loss of Estuarine Sediment Flats, Environ. Manage., vol. 53, no. 1, 2014, pp. 163171.

[4] Scheingross, J.S., Brun, F., Lo, D.Y., Omerdin, K., and Lamb, M.P. Experimental evidence for fluvial bedrock incision by suspended and bedload sediment, Geology, vol. 42, no. 6, 2014, pp. 523526.

[5] Naqshband, S., Ribberink, J.S., Hurther, D., and Hulscher S.J.M.H. Bed load and suspended load contributions to migrating sand dunes in equilibrium, J. Geophys. Res. Earth Surf., vol. 119, no. 5, 2014, pp. 1043-1063.

[6] Yuliarahmadila, E., Adnan, M.S., Noorfathiah, C.A., Amat, N.F., Zawani,M.Z. Comparison of Distribution Methods of Low Flow Analysis for Bandar Segamat, Johor, Applied Mechanics and Materials ,Vol. 773-774, 2015, 1266-1270.

[7] Nilsson, C. Fragmentation and Flow Regulation of the World's Large River Systems, Science (80-. ) vol. 308, no. 5720, 2005, pp. 405-408.

[8] Jyvitski, J.P.M. Impact of Humans on the Flux of Terrestrial Sediment to the Global Coastal Ocean Science (80-. )., vol. 308, no. 5720, 2005, pp. 376380.

[9] Yu, S., Yang, J., and Liu, G. Impact assessment of Three Gorges Dam's impoundment on river dynamics in the north branch of Yangtze River estuary, China, Environ. Earth Sci., vol. 72, no. 2, 2014, pp. 499-509.

[10] Yuan, W., Yin, D., Finlayson, B., and Chen, Z. Assessing the potential for change in the middle Yangtze River channel following impoundment of the Three Gorges Dam, Geomorphology, vol. 147148, 2012, pp. 27-34.

[11] Reid, I., Layman, J.T., and Frostick, L.E. The Continuous Measurement Of Bedload Discharge, $J$. Hydraul. Res., vol. 18, no. 3, 1980 pp. 243-249.

[12] Van Rijn, L.C. Sediment Transport, Part I: Bed Load Transport, J. Hydraul. Eng., vol. 110, no. 10, 1984, pp. 1431-1456.

[13] unte, K., Abt, S.R., Potyondy, J.P., and Ryan, S.E. Measurement of Coarse Gravel and Cobble Transport Using Portable Bedload Traps, J. Hydraul. Eng., vol. 130, no. 9, 2004, pp. 879-893.

[14] Xu, K., and Milliman J.D. Seasonal variations of sediment discharge from the Yangtze River before and after impoundment of the Three Gorges Dam, Geomorphology, vol. 104, no. 3-4, 2000, pp. 276-283. 